International Journal of Instruction e-ISSN: 1308-1470 • www.e-iji.net

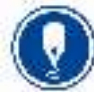

April 2021 • Vol.14, No.2

p-ISSN: 1694-609X

pp. 233-252

Article submission code:

20190731081114

Received: 31/07/2019

Revision: 08/09/2020
Accepted: 01/10/2020

OnlineFirst:21/01/2020

\title{
Backward Instructional Design based Learning Activities to Developing Students' Creative Thinking with Lateral Thinking Technique
}

\section{Wandee Srikongchan}

Faculty of Industrial Education and Technology, King Mongkut's University of Technology Thonburi, Thailand, wandee.1979@mail.kmutt.ac.th

\section{Sittichai Kaewkuekool}

Faculty of Industrial Education and Technology, King Mongkut's University of Technology, Thailand, sittichai.kae@kmutt.ac.th

\section{Sopon Mejaleurn}

Faculty of Industrial Education and Technology, King Mongkut's University of Technology, Thailand, sopon.mee@kmutt.ac.th

Creative thinking has been considered a vital foundation for students. Owing to existing instructional strategies, students are not well promoted for creative thinking. This study addresses this challenge by proposing an instructional approach that integrates the strengths of backward instructional design and lateral thinking to promote students' creative thinking. A series of learning activities were developed in the context of grade-5 Information Technology subject in Thailand. Each learning activity was designed to develop a major element of creative thinking in an authentic experience. The students were encouraged to think, participate, and interact with different points of view based on either internal or external stimulation. The approach has been tested and improved before the implementation. To investigate the effectiveness of the proposed instruction on developing students' creative thinking, this study conducted a quasi-experimental research method for 12 weeks with 60 fifth graders in a school in Thailand. All students were grouped by cognitive styles and joined in two lateral techniques (30 students with field dependence and 30 students with field independence cognitive style). The results of their creative thinking from TTCT-Figural (Form A) showed that all students have significantly improved their creative thinking after learning with the proposed learning activities. Students with field dependence thinking style improved their scores from 53.83 to $78.77(\mathrm{t}=15.525, \mathrm{p}=0.000)$, while those with field independence thinking style improved their scores from 46.93 to 78.13 (t $=14.564, \mathrm{p}=0.000$ ).

Keywords: instructional design, backward design, lateral thinking, creative thinking, information technology

Citation: Srikongchan, W., Kaewkuekool, S. \& Mejaleurn, S. (2021). Backward Instructional Design based Learning Activities to Developing Students' Creative Thinking with Lateral Thinking Technique. International Journal of Instruction, 14(2), 233-252. https://doi.org/10.29333/iji.2021.14214a 


\section{INTRODUCTION}

Creative thinking has been considered as an essential skill which required imagination, the individuals could be led to many possible ideas and solutions with creative thinking skill (Rahardjanto, Husamah \& Fauzi, 2019; Rawlinson, 2017; Yusnaeni, Corebima, Susilo, \& Zubaidah, 2017). It is one of the cognitive abilities that perform divergent thinking with fluency, flexibility, and originality (McAuliffe, 2016). Moreover, it enables the persons to understand the problems and expect the following situations; consequently, they can solve the problems effectively (Kuswanto, 2018). Besides, many studies have continuously reported that creative thinking plays a crucial role for children in promoting learning discipline, creativity, and cognitive development (Fasko, 2001; Tan, 2007). It leads the children to accept and open to a new perspective, understand the current limitation, and find the opportunity from the failures of the problems (Wojciehowski \& Ernst, 2018). To develop this skill for children mainly, they need to have a learning experience in creative problem solving, brainstorming, and inquiry process (Dillon, Graham, \& Aidells, 1972; Torrance, 1962).

However, many schools' educational contexts do not provide this experience to the students due to the flaws in instructional design. Students in many classes are taught to learn the same topic with the same instructions and activities given by the teachers. Such that, the students are directed to think in the same pattern to understand the contents, working the projects, and generating the solutions. They are not encouraged to think differently or think out of the box. Consequently, they cannot develop new ideas, new methods, and new solutions that would be different from the existing ones. In the meantime, many studies have found that these students have lower learning performance compared to those who showed a higher degree of creative thinking (Nuha, Waluya, \& Junaedi, 2018; Rahardjanto \& Fauzi, 2019).

In 1972, White reported that lateral thinking technique could promote creative thinking development for children. This technique induces the children to make conceptual analysis to make the changes; leading to think differently. Meanwhile, Wiggins and McTighe (1998) proposed the instructional development approach, called backward design, to enduing students' learning understanding. The concept of this approach is first setting the learning goal and design the teaching instructions and activities back to the beginning. The teacher can determine the acceptable evidence for such learning durability; hence, the teachers can plan learning experiences.

Therefore, developing students' creative thinking at early school ages is crucial. It has been widely accepted as a foundation to develop further skills, competences, and innovations in their lifetimes. Meanwhile, only a few research studies considered designing the instruction by identifying the desired learning goals first. In addition, the learning process was not provided accordingly, while the learning activities fairly integrated the authentic learning context and environment and students' different thinking styles into consideration. To develop this essential thinking skill, lateral thinking is one of the well-known techniques that can be integrated into the school instruction programs. It allows students to see the problems or situations from different perspectives and enable them with imagination to seek for many opportunities. 
Based on this perspective, this study aims to address such issues by proposing an instructional approach with the backward design by incorporating with the lateral thinking technique. With this instructional design, the desired learning results of students are firstly identified, followed by the learning activities which can be directed to those goals. The activities are designed to fit students' learning context and experience in order to foster them to think creatively by following the concepts of lateral thinking technique. In addition, different stimulations are given according to their cognitive styles, while the guidelines to assess their creativity on various learning activities is prepared.

To reach the main purpose of this research study, an empirical study has been carefully designed and conducted with fifth-grade students in an Information Technology course to investigate their creative thinking development with the proposed learning approach. Accordingly, a research hypothesis was made that the students who learned with the proposed learning approach could have their creative thinking developed. The findings of this study would emphasize the significance and necessity of developing students' creative thinking from the carefully designed instruction that considers the different styles of learners, the desired learning outputs, and the engaging learning activities that relate with their background and experience. More importantly, opportunities to understand the situations or problems should be guided in order to ignite imagination to different possible solutions and ideas.

\section{LITERATURE REVIEW}

\section{Lateral Thinking Technique (LTT)}

Lateral thinking was defined as the endeavor process for systematic thinking which brings creative thinking, it is the process to solve the problems creatively. The process might seem irrational at the beginning, but can be somehow applied later on (Semerci, 2017).

Lateral thinking technique (LTT) can be separated into two phases: avoiding the old thought. At this phase, try to figure out how to ignore the existing ideas and perspective, and look for the different methods. Second, motivating new idea. At this phase, focus on finding a different method to solve the solution rather than considering the accuracy of the ideas. This could make the opportunity to generate a new solution. Moreover, Mugisha (2009) showed that LTT could be developed in three dimensions: attitude, provocative operation, and technique and skill.

Most literatures agree that developing LTT can be most effective with these two techniques: change from within and change from outside. The former requires an initial analysis of the existing concept, then leading to new ideas. This can be done by reversing the thinking, and distorting/exaggerating the thinking, e.g., present the information with a different shape, not the typical rectangular shape. The latter brings the external surrounding/stimulation to cultivate the new ideas. This can be done by using random words to trigger different thinking and getting exposed to the different environment, e.g., taking the children to new locations, meet new environments (Doppelt, 2009; Lamb, Annetta, \& Vallett, 2015). 


\section{Backward Instructional Design}

Backward design is used to design the instruction in creative, collaborative and purposeful way by identifying the desired learning results, then followed by designing the learning and instruction activities to meet that goal (Wiggins, G \& McTighe, 2005; Fried \& Harper, 2018). This approach can help the teacher to prepare materials systematically and help students to learn meaningfully.

Backward instructional design can be accomplished in three stages: design the learning goals, identify the learning evidence and measurement, and design the instruction. In the first stage, the teacher needs to set the desired learning results by identifying the learning topics; moreover, the teacher must identify what knowledge and skills should be equipped with the students to enduring their understanding (G. P. Wiggins \& McTighe, 2007). In the students' perspective, it can be presented as the learning is worth being familiar with, it is important to know and to do, and it is enduring understanding. In the second stage, the teachers should determine the acceptable learning evidence following the curriculum requirements at least. The teachers may consider the following behaviors as the students present the learning evidence, such as explanation, interpretation, application, having perspectives, empathies, and self-knowledge. Therefore, the teachers need to prepare for the measuring tools for proper evidence. Some possible pieces of evidence can be an essay, a piece of writing, drawing diagram, giving an oral presentation, conducting an interview, and performing the role play, the stage show. In the final stage, the teachers can plan and design the learning experience and instructions accordingly. At this moment, the teacher should consider the authentic learning activities that reflect the desired objectives, also promote the students' capabilities. Importantly, they must be measured.

In the past years, many studies have applied backward design instruction in different cases worldwide. For example, Kelting-Gibson (2003) compared two lesson designs (traditional and backward design) on the Educational Planning and Management topic. It was found that the teachers who experienced the proposed lesson design based on backward design could accomplish the goals faster than the other groups. Moreover, some teachers applied this lesson design in science, language, social studies, arts, physical education, and mathematics (Dahlke, 2018; Joyce \& Swanberg, 2017; Ontaneda Rea \& Sánchez Román, 2019). They consistently found that the students who learned with backward design-based lesson could learn better than those who learned with traditional lesson designs; moreover, they were found better learning motivation towards the learned lessons.

\section{Field Independence/Field Dependence Cognitive Style}

Cognitive style is defined as an operational character that the individuals perceive and use the information as a tool to indicate their behavior (Adomako, Danso, Uddin, \& Damoah, 2016; Jelatu, Kurniawan, Kurnila, Mandur, \& Jundu, 2019; Sujito \& Muttaqin, 2020). This affects how the person interprets and understands data, and makes use of it (Thornton \& Lukas, 2012). A person tends to handle a chunk of data in the same pattern or style for different situations. Ausburn and Ausburn (1978) summarized cognitive 
style into eleven dimensions, e.g., field dependent/field independent, scanning/focusing, reflectivity/impulsivity.

One of the most widely accepted dimensions is field dependence (FD) /field independence (FI) (Dent, 1983). This dimension, which is believed to remain stable for a person, can predict the person's cognitive and social operations through the surrounding environment. Witkin et al. (1977) developed a Group Embedded Figures Test (GEFT) to measure multiple persons' cognitive style at the same time. Those who are examined FD are likely to consider the data or stimulation as a whole, not in details, and use their prior experience to examine them. To say, this FD style's persons usually are under control of the surrounding environment. In contrast, those who are examined FI are likely to perceive data or stimulation with in-depth analysis. They could solve the situations or complex incidents confronting them well. In other words, this FI style's persons could manage the surrounding environments. Moreover, it was found that FI persons are good at learning mathematics and science, while FD persons are good at learning social studies (Dent, 1983).

This topic has been widely studied in the past decade. For example, it was found that FI students revealed higher problem-solving score on web learning system than those with FD style; moreover, when FD students receive the learning guidance, they could perform better than the other group. By categorizing students into FD/FI cognitive style, it was later found that both groups solved learning problems differently (Ausburn \& Ausburn, 1978; Onyekuru, 2015; Witkin et al., 1977). Yang, Hwang, and Yang (2013) developed a personalized learning system by taking students' cognitive style into consideration of providing a user interface and navigation strategies.

Therefore, this study considered the participants' cognitive style on FD/FI dimension by adopting GEFT as a tool to categorize them in investigating the effects of the proposed approach on their lateral thinking.

Development of Backward Instructional Design Based Learning Activities to Developing Students' Creative Thinking with Lateral Thinking Technique (LTTCreative)

\section{Overall Approach Structure}

Based on the advantages of lateral thinking technique and backward instructional design, this paper has developed a series of learning activities with the instructional process to develop students' creative thinking, hereinafter called LTT-CREATIVE. As shown in Figure 1, this proposed approach integrates lateral thinking technique, that has two types, change from within and change from outside, with the developed learning activities on grade-5 Information Technology subject. This integration part will be used in the phase of the learning process for developing creative thinking, as part of a backward instructional design. 


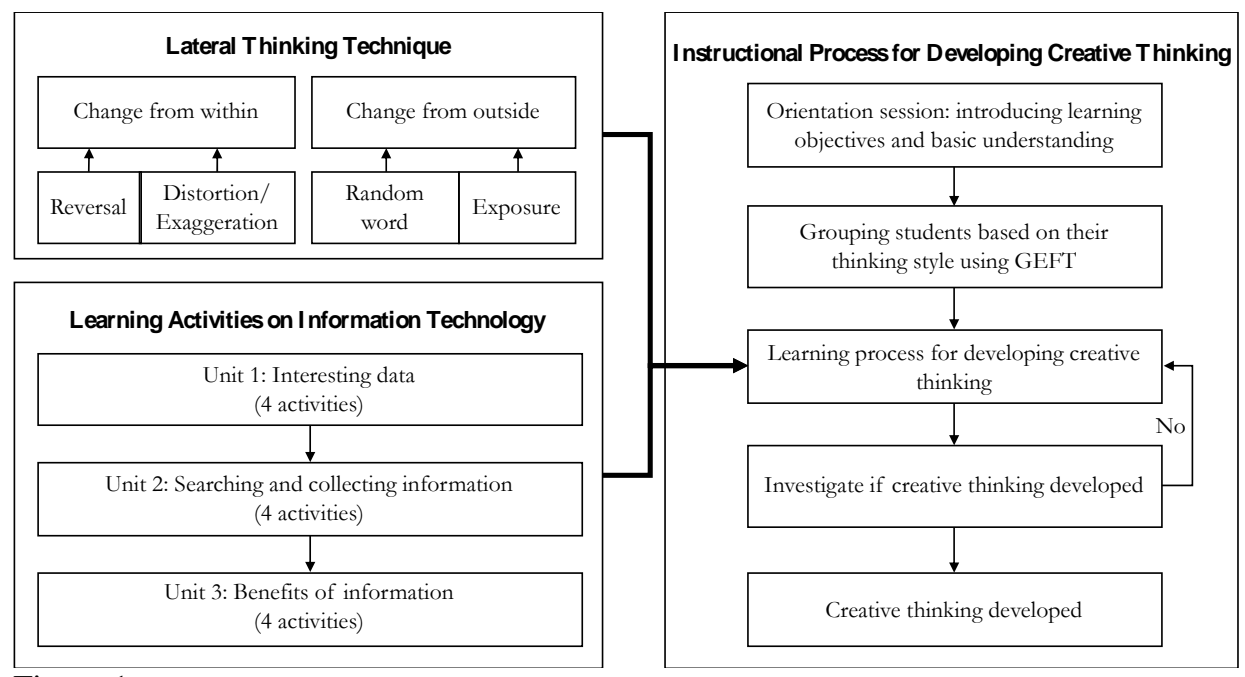

Figure 1

A structure of backward instructional design approach based on lateral thinking technique to promoting students' creative thinking (LTT-CREATIVE)

The instructional process was developed in parallel to the backward instructional design. This process will start by introducing the learning goals and providing basic knowledge. After that, students will be categorized by their cognitive style before participating in the learning activities. The teachers in the meantime investigate if students have developed their creative thinking; otherwise, they need to rejoin the activities. This rejoining is restricted to the objectives of each learning activity, leaving no different effect on measuring the impact of this proposed instruction. Only remedial activities and constructive feedbacks are given to improve their creative thinking to reach the accepted level of creative thinking development, which is similar to other students. For example, more explanations are presented in detail. Consequently, students are expected to improve their creative thinking.

\section{Learning Activities Design and Development}

In order to make learning process that can develop students' creative thinking, this study developed a series of learning activities by using the content of grade- 5 Information Technology subject in Thailand. The created learning activities can be separated into three learning units; each comprises of four activities. Each learning unit was designed in corresponding to four components of creative thinking that are fluency, originality, flexibility, and elaboration. Each learning activity will promote one of the creative thinking components, as shown in Figure 2. For example, Activity 1 promotes fluency. Activity 2 promotes originality. Activity 7 promotes flexibility, and so on. 
Learning Activities on I nformation Technology

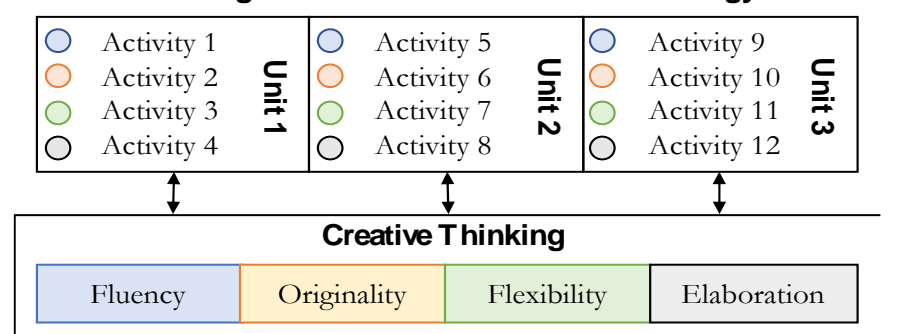

Figure 2

A structure of learning activities and creative thinking

To better understand how each learning activity can help promote creative thinking under the context of grade-5 Information Technology content, three activities, Activity 6, 9 and 10, are raised and explained in detail here.

In Activity 6, it was designed to promote students' originality. The students are prompted with this activity sheet and are encouraged to develop a story upon what they see in the picture, as shown in Figure 3 (top-left). The teachers can foster students to originate the story with external and internal stimulations. For example, what is going on TV now and how can they connected. The students then visualize their thoughts or ideas on the available space.

Activity 9, it helps students to develop creative thinking's fluency. The students are given with the many empty boxes to fill up with any IT devices that they know, as shown in Figure 3 (below). In this activity, the teachers also foster students' fluency by external surroundings. Also, the teachers can also ignite with their internal stimulation, e.g., what do you use to type the text to the computer, what do you use to download the apps, etc.

Activity 10 , it helps to promote students' originality. This activity is more advanced than those in Activity 2 and 6. As shown in Figure 3 (top right), the students are given some public issues and are asked to select one issue to propose a solution for. The teachers at this moment can encourage them to think out of the box by originating different, new solution with some stimulations, which can be opened on a computer and can be raised by any questions or discussions. Therefore, students can present their originality to solve the issue differently. 

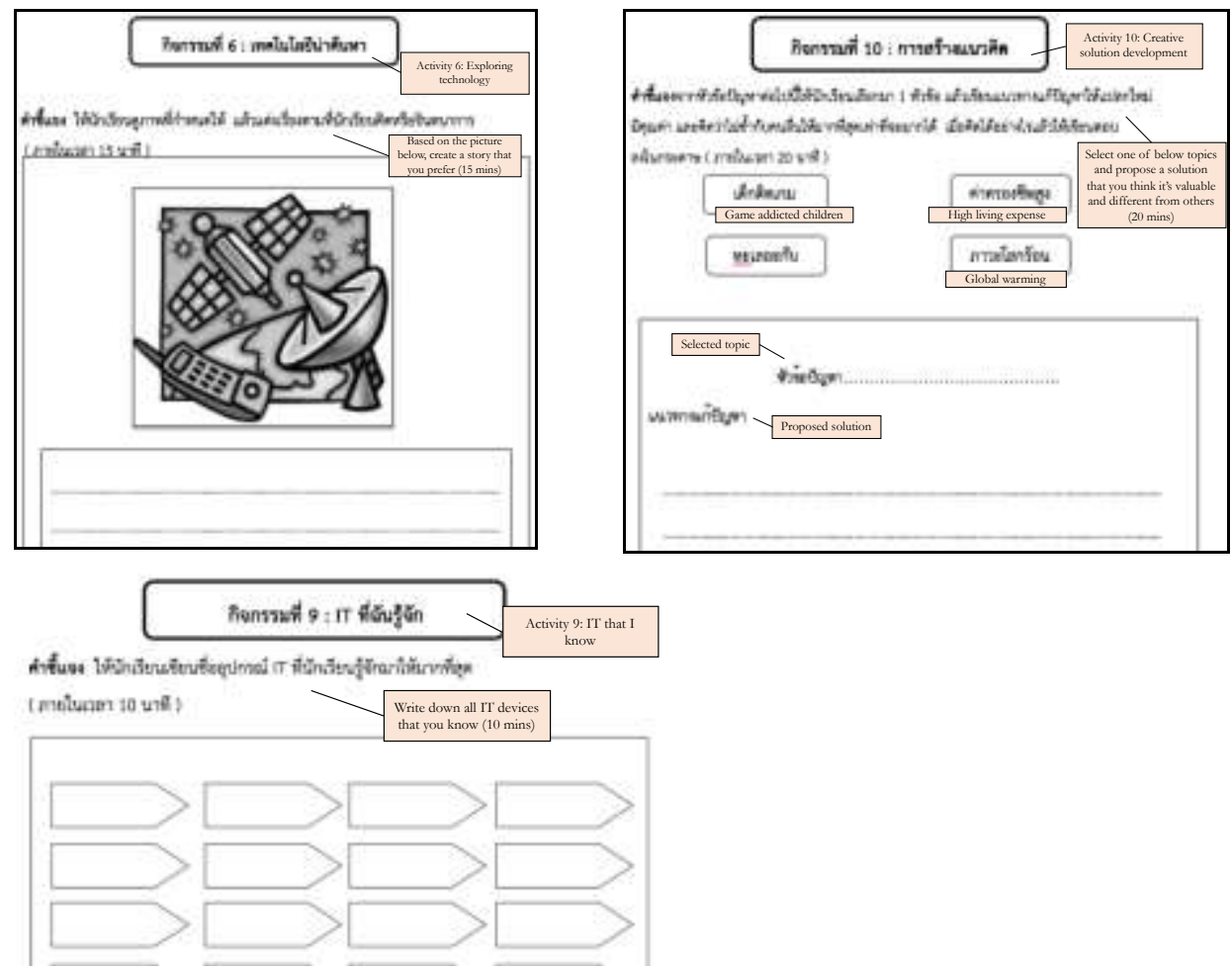

Figure 3

Activity sheets for recording creative thinking

It can be found that all twelve activities across three learning units were designed to develop creative thinking on four elements: fluency, originality, flexibility, and elaboration. These activities are provided to the students by following lateral thinking techniques, which consider students' cognitive styles and different stimulations. They are promoted to understand the problems, situations, or phenomena in different perspectives based on stimulations. It enables students to find new possible opportunities and solutions creatively. These essential modules are given as part of the proposed instructional design as the learning process to develop students' creative thinking.

\section{Approach Validation}

Once LTT-CREATIVE approach was completely developed, it has gone through a series of validation in order to improve for the final use. Six experts in the relevant fields have firstly validated the approach, three specialized in creative thinking, and three specializes in technology education. Each held a minimum degree of Ph.D. with at least five years of in-service experience. Each expert was asked to assess the proposed approach on multiple items of Likert scale-typed questionnaire. With this assessment, it 
was found that some of the drawings in activities were not details enough to be understood by the students. Also, the description of activities was too narrative, which was a bit difficult to follow. By taking the experts' comments, the authors have improved the activities by making drawings with more details and recompositing for the clear understanding and revise the description in stepwise numbering accordingly. After that, the revised approach has been tried with a small group of students. They were in a similar type of those who are in the experimental phase. Three rounds of this trial were done with 12 students who never learned this subject before. As a result, it was found that all students have improved their creative thinking; therefore, this approach is now ready for a real experiment to seek for the findings.

\section{METHOD}

\section{Research Method}

In this study, a quasi-experimental research method has been conducted. The experiments were provided to the samples in two experimental groups with no control group and no randomization of selecting users. Pretest and posttest were assigned before and after the experiments, respectively. A context and learning activities of grade-5 Information Technology subject in Thailand were implemented in the proposed learning instruction approach, while a school teaching this subject for two periods a week was recruited in this study.

\section{Research Participants}

This study applied a purposive sampling method based on the convenience and time availability of the samples and the researchers. The participants in this study are fifthgrade students from two available classes of a selected school in Thailand, where the researchers worked and taught. There are 30 students in each class, a total of 60 students. All students have enrolled in an Information Technology subject and have learned with the same teacher to avoid the learning experience difference.

\section{Research Instruments}

\section{Group Embedded Figures Test (GEFT)}

GEFT was developed by Oltman, P. K., Raskin, E. and Witkin (1971) to categorize cognitive styles of over 10-year old people into two types: field dependence (FD) or field independence (FI). The test consists of 18 items, whose score is between 0-9 and 10-18 are considered FD and FI respectively. GEFT has been accepted for a good level of validity and reliability by many studies (Acero, 2019; Raptis, Fidas, \& Avouris, 2016; Setiawan, Purwanto, Parta, \& Sisworo, 2020).

\section{Torrance Test of Creative Thinking}

TTCT is based on Guilford's model of divergent thinking that leads to a unique solution (Torrance, 1967). This study only applied the Figural Test (Form A), starting now called TTCT-Figural (Form A). It comprises of three sets on improving figure from the stimulation, completing the figure, and drawing the figure from parallel lines. This test 
can assess four components of creative thinking, including fluency, originality, flexibility, and elaboration. This test has been widely accepted for a good level of validity (Hahm, Kim, \& Park, 2019; Krumm, Arán Filipppetti, Lemos, Koval, \& Balabanian, 2016; Perry \& Karpova, 2017). Please note that TTCT-Figural (Form A) used in the pretest and posttest is the parallel version to assess students' creative thinking, where some examples are slightly different, and questions are shuffled to avoid the memorization but maintain the test's objectives.

\section{Research Procedure}

The experiment of this research can be divided into three major phases, see Figure 4. In the first phase (one week), all students were categorized into two groups either FD or FI based on the results of GEFT. In the meantime, they all took the same test TTCTFigural (Form A) to assess their creative thinking before learning with the proposed approach. Before the experiment, the orientation session was provided to all students to understand the objectives and procedures of the experiment.

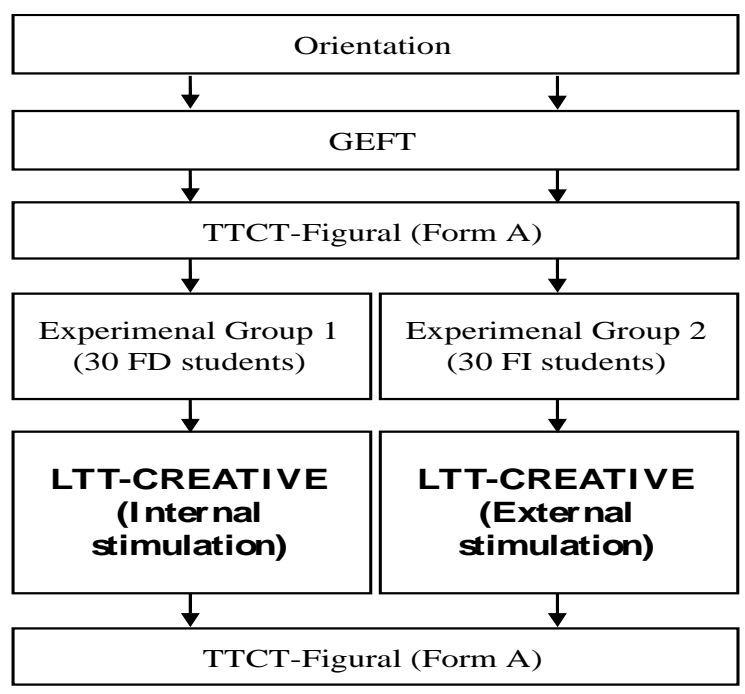

11 weeks

Figure 4

Overall research procedure

In the second phase, all students were separated into two groups (classes); $30 \mathrm{FD}$ students in one group and 30 FI students in another group. In the first group, called Experimental Group 1, the students learned with LTT-CREATIVE approach with internal stimulation, known as change from within. In the second group, called Experimental Group 2, the students learned with LTT-CREATIVE approach with external stimulation, known as a change from outside. This phase lasted for 11 weeks, each with two periods of regular Information Technology class hour. 
After students have experienced in the proposed LTT-CREATIVE approach for 11 weeks, it is time to assess their creative thinking. In this third phase (1 week), students took TTCT-Figural (Form A) to examine how their creative thinking has changed.

\section{FINDINGS}

As presented in Table 1, the average posttest scores of Experimental Group $1(X=$ $78.77, S D=13.78)$ and Experimental Group $2(X=78.13, S D=18.47)$ were not significantly different $(t=0.151, p=0.881)$. This result can be implied that the difference of stimulations, change from within and change from outside, in LTTCREATIVE approach had no effect on the students' creative thinking. Both groups of students have achieved a great level of creative thinking due to the fact that each group received the appropriate stimulation to improve their creativity that matched their cognitive style. It allowed students to think and imagine in different perspectives; meanwhile find new opportunities under the existing limitations. Therefore, both groups had no difference on the creative thinking after experiencing the proposed LTTCREATIVE.

Table 1

Posttest's creative thinking scores of two lateral thinking techniques

\begin{tabular}{llll}
\hline Group & Posttest Score $(X \pm S D)$ & $t$ & $p$ \\
\hline Experimental Group 1 $(n=30)$ & $78.77 \pm 13.78$ & 0.151 & 0.881 \\
\cline { 1 - 3 } Experimental Group 2 $(n=30)$ & $78.13 \pm 18.47$ & & \\
\hline
\end{tabular}

However, it was found that both experimental groups have significantly improved their creative thinking scores, as shown in Table 2. In Experimental Group 1, students have improved from pretest scores $(X=53.83, S D=7.68)$ to posttest scores $(X=78.77, S D=$ 13.78) significantly $(t=15.525, p=0.000)$. In Experimental Group 2, students have significantly improved $(t=14.564, p=0.000)$ from pretest scores $(X=46.93, S D=$ 9.37) to posttest scores $(X=78.13, S D=18.47)$.

Table 2

Pre- and post- tests' creative thinking scores of two lateral thinking techniques

\begin{tabular}{lllll}
\hline Group & $\begin{array}{l}\text { Pretest Score } \\
(\mathrm{X} \pm \mathrm{SD})\end{array}$ & $\begin{array}{l}\text { Posttest Score } \\
(\mathrm{X} \pm \mathrm{SD})\end{array}$ & $t$ & $p$ \\
\hline Experimental Group 1 $(n=30)$ & $53.83 \pm 7.68$ & $78.77 \pm 13.78$ & 15.525 & $0.000^{* * *}$ \\
\hline Experimental Group 2 $(n=30)$ & $46.93 \pm 9.37$ & $78.13 \pm 18.47$ & 14.564 & $0.000^{* * *}$ \\
\hline
\end{tabular}

$* * * p<0.001$

This result can be seen in Figure 5 for their improvement of creative thinking from LTTCREATIVE approach with two techniques. It can be implied that the learning activities and learning experience of LTT-CREATIVE approach could provide students a meaningful learning process; in the meantime, help the students developed creative thinking. In other words, this finding showed that the proposed learning activities in LTT-CREATIVE are effectively designed in corresponding to students' cognitive style. The right stimulation for each cognitive style can help foster students gain better learning experience while improving creative thinking through the learning process. 
They were encouraged by the matched stimulations that motivate them to think, try, or solve the problems with new perspectives and imagination.

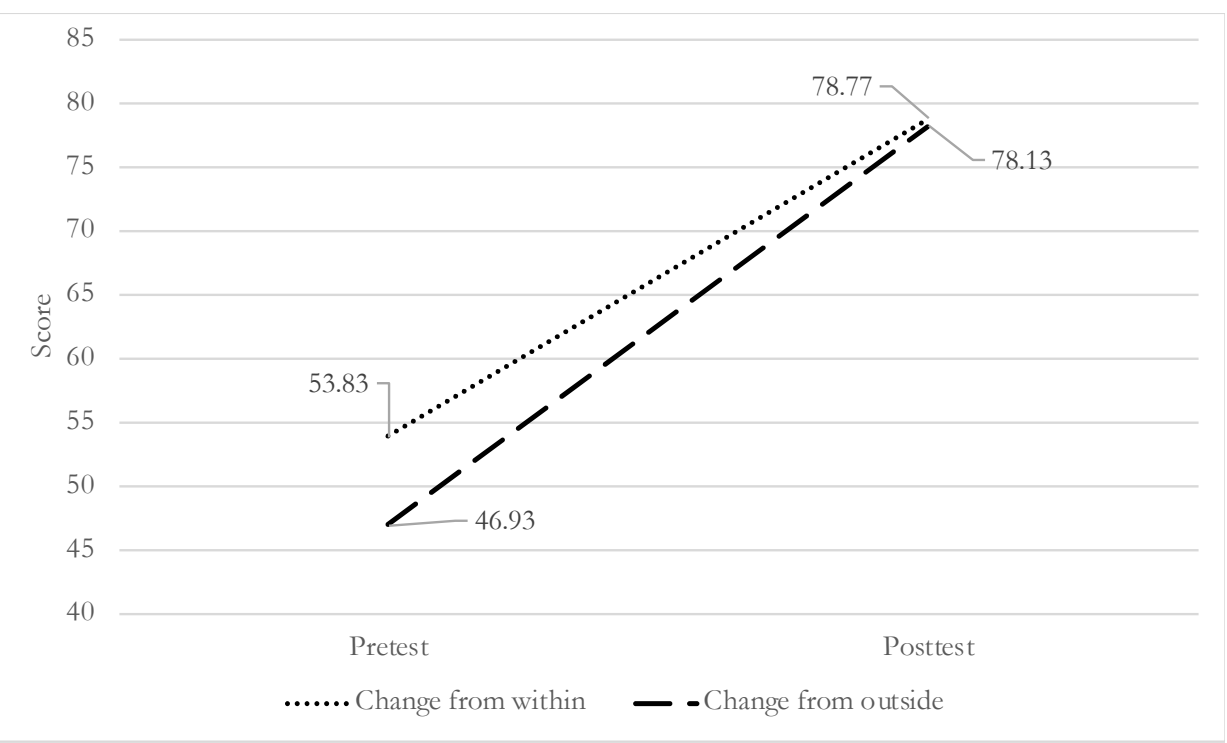

Figure 5

Pre- and post- test scores on two lateral thinking techniques

In considering to the difference of students' cognitive styles, it was found that FD students have no significantly difference $(Z=0.727, p=0.467)$ on posttest scores on both Experimental Group $1(X=79.67, S D=11.68)$ and Experimental Group $2(X=$ $82.20, S D=15.86$ ), as shown in Table 3. Moreover, FI students have no significantly difference $(Z=0.560, p=0.575)$ on posttest scores on both Experimental Group $1(X=$ 77.87, $S D=15.97)$ and Experimental Group $2(X=74.07, S D=20.49)$. This result means that LTT-CREATIVE approach is effective to both cognitive styles of students, field dependence and field independence, making both lateral thinking techniques significantly improved their creative thinking.

Table 3

Posttests' creative thinking scores of FD/FI students on two lateral thinking techniques

\begin{tabular}{|c|c|c|c|c|c|c|c|}
\hline \multirow[t]{2}{*}{ Group } & \multicolumn{2}{|c|}{$\begin{array}{l}\text { Posttest } \\
\text { (Change from within) }\end{array}$} & \multirow[t]{2}{*}{ Score } & \multicolumn{2}{|c|}{$\begin{array}{l}\text { Posttest Score } \\
\text { (Change from outside) }\end{array}$} & \multirow[t]{2}{*}{$Z$} & \multirow[t]{2}{*}{$p$} \\
\hline & $n$ & $\mathrm{X} \pm \mathrm{SD}$ & & $n$ & $\mathrm{X} \pm \mathrm{SD}$ & & \\
\hline FD & 15 & $79.67 \pm 11.68$ & & 15 & $82.20 \pm 15.86$ & -0.727 & 0.467 \\
\hline FI & 15 & $77.87 \pm 15.97$ & & 15 & $74.07 \pm 20.49$ & -0.560 & 0.575 \\
\hline
\end{tabular}

Based on the experimental results, the findings showed that the proposed learning process of LTT-CREATIVE helped students with different cognitive styles improved their creative thinking significantly. In the meantime, the appropriate stimulation to foster students play a crucial role in this creativity improvement based on the technique 
of lateral thinking. This phenomenon was made possible by encouraging them to understand, think and design with different perspectives; meanwhile, seeking for the new possible solutions.

\section{DISCUSSION}

Creative thinking development plays an essential function in the school-age years as a necessary foundation for other skills. The existing instructions are inadequately designed to encourage students to understand the problems or any situations differently though their learning process; consequently, their imagination to initiate new ideas and solutions is limited. Moreover, creative thinking can be well enhanced when the students are given the proper stimulations during the learning activities, as they have different thinking styles.

With that, this study addresses such issues by adopting two techniques of lateral thinking, including change from within and change from outside to design an instruction to enhance students' creativity, called LTT-CREATIVE. The proposed learning instruction was designed with the backward instructional design approach by firstly setting the desired goal, which is undoubtedly creative thinking, followed by the learning sequence and learning activities accordingly. The learning process in LTTCREATIVE was designed to help promote students' creative thinking through 12 learning activities in three learning units, which include fluency, originality, flexibility, elaboration. The learning activities were developed under the context of Information Technology course based on their experience and learning background. While experiencing each activity, the students are guided to think and consider the situations differently upon the stimulation received based on their thinking style.

To understand the effect of the proposed instruction, an experiment was carried out with the students of Information Technology course. Based on the experimental results, we have found that the students had improved their creative thinking skill; besides, both lateral thinking techniques could encourage creative thinking. Consequently, the students with different cognitive styles of field dependence and field independence both gain benefits from this approach. In addition, the result found that both techniques of lateral thinking, change from within and change from outside, could support creative thinking development; it is due to the designing phase of learning activities to cover both stimulations, as shown in Figure 3. Each learning activity considered students' style of perceiving and thinking, making both cognitive styles, field dependence, and field independence gained benefits of the presented learning activities.

Based on the result shown on Table 2 that the students significantly improved creative thinking, it is due to a careful design of learning activities to correspond with the components of creative thinking that include fluency, originality, flexibility, elaboration (Fasko, 2001). These activities could help the students to improve their creative thinking while experiencing activities in the proposed learning instruction. In addition, this result aligns with several research studies as they attempted to address the creative thinking issue with different styles of instruction. For example, Lamb, Annetta and Vallett (2015) designed serious educational game in science classroom to promote creativity, while 
Kuswanto (2018) developed mobile application for Physics learning to improve creative thinking and problem solving and Rahardjanto and Fauzi (2019) developed an innovative hybrid project-based learning model to enhance creative thinking and learning motivation of preservice teachers. In addition to the learning activities, the proposed instruction was initially developed by setting the desired learning goals that was to develop creative thinking. Regarding these goals, they help manage the sequence of learning and make activities more meaningful and logical in a good direction to desired goals. Moreover, the teachers know the purpose of each learning sequence as a foundation of next sequence. In other words, the teacher is aware of the importance of current activity before moving to the next activity. Besides, desired learning goals keep designing activities covering most possibilities of learning outcomes generated at each step (Gillan \& Robbins, 2014; Moynihan, 2005).

Key findings of this research have unveiled some significance. The design of learning instruction to promote students' creative thinking that focuses on the desired learning outcome can help develop the learning process and learning activities effectively. Besides that, creative thinking enhanced learning activities should be developed to cover four major dimensions: fluency, originality, flexibility, and elaboration; in the meantime, they need to be strongly connected with the students' background and experiences and can be directed with two different stimulations based on lateral thinking technique. Finally, understanding students' thinking style could help the teacher to provide the relevant stimulation to students' understanding and imagination process, which significantly influence creative thinking development.

The findings reveal some alignments with other studies regarding learning goals-based instructional design in different aspects. In the dimension of improving the learning performance of the students, our finding is in accordance with Chang (2019), which found a significant enhancement of the students' creativity after participating in the activities that considered the students' cognitive styles and differentiated them in the study. On the other hand, our study's result is differed from Noppe and Gallagher (2010), as they implemented the cognitive styles approach to creative thought and found that the FI students had higher scores for both Remotes Associates Test (RAT) and Group Embedded Figures Test (GEFT) than FD students.

Regarding students' learning preferences, Lo, Chan, and Yeh (2012) considered students' cognitive styles when designing an adaptive web-based learning system; they achieved that the adaptive web-based learning system integrating with students' cognitive styles can result in the various information organization and students' process preferences. Tsai and Lin (2017) studied the behavioral learning patterns with cognitive styles on Augmented Reality game; they revealed that the students' cognitive styles could be classified and determined the students' behavioral differences. Ehrman and Leaver (2003) enhanced individual language learning by understanding students' cognitive styles; they contend that the Ehrman-Leaver cognitive style construct (E\&L) provides a variety of information about the students and language learning and useful for assisting in finding suitable learning strategies for the students. In conjunction with these 
three studies, this study integrated the students' cognitive styles for identifying the students' thinking styles and providing suitable learning processes and activities.

\section{CONCLUSIONS AND RECOMMENDATIONS}

This study presents a learning instruction to enhance creative thinking. The proposed learning instruction was designed following a backward design approach, which firstly identifying the desired learning outcome of creative thinking development before design the learning activities. This enables the learning process more effective sequence and support key concepts of creative thinking. The learning activities were developed in corresponding to students' background and experience, which could encourage them to think and understand the given activities differently based on the received stimulations on lateral thinking technique. From the experimental results, it enables more understanding that the proposed instruction incorporated with lateral thinking technique and backward design strategy could help students improve their creativity. Furthermore, the developed learning activities can be applied in the actual classroom as a supplementary or replacement. Also, the proposed learning instruction could foster the students to think laterally, which is considered as a concrete foundation to create future innovations (de Bono, 1990; Lamb et al., 2015).

From findings of this study, several recommendations can be finally made as follows.

- It has been understood that to design learning activities, the teachers need to take students' learning background and difference into consideration; specifically, this study developed students' creative thinking by considering students' thinking style and lateral thinking technique. From proposed learning activities of this study, the teachers may also apply them in corresponding to the course's objectives and indicators, while some modifications can be made to provide different learning experiences, which can influence the lateral thinking

- Setting learning environment also plays a crucial role in developing creative thinking as it fosters students to think, design, attempt and participate. Therefore, administration staffs should give this priority and support learning facility in the harmony way. In addition, the assessment and evaluation to be more flexible and agreeable with the learning difference generated by this study. Likewise, the observation of learning behavior during the learning process is vital; therefore, facilitators could be helpful.

Although the proposed learning instruction could help students to develop their creative thinking, this study can be further investigated and improved. Regarding research methodology, this study did not conduct a comparative study with the traditional instruction or other existing formats; therefore, we could not consider the effect of proposed learning instruction in comparison with others (An, Song, \& Carr, 2016; Babu et al. 2018). Moreover, this study did not reflect the qualitative aspect of data, e.g., learning attitude, students' feedback, or learning satisfaction towards the proposed instruction; therefore, these learning variables can be examined in future studies to understand in-depth phenomena (Cheng, 2014; Noh, Kang, \& Jung, 2015). 


\section{REFERENCES}

Acero, E. J. (2019). High scores in the embedded figures test correlate with tissue diagnostic speeded. Retrieved from https://www.fasebj.org/doi/abs/10.1096/fasebj.2019.33.1_supplement.802.63

Adomako, S., Danso, A., Uddin, M., \& Damoah, J. O. (2016). Entrepreneurs' optimism, cognitive style and persistence. International Journal of Entrepreneurial Behaviour and Research, 22(1), 84-108.

An, D., Song, Y., \& Carr, M. (2016). A comparison of two models of creativity: Divergent thinking and creative expert performance. Personality and Individual Differences, 90, 78-84.

Ausburn, L. J., \& Ausburn, F. B. (1978). Cognitive styles: Some information and implications for instructional design. Ectj, 26(4), 337-354.

Babu, S. K., Krishna, S., Unnikrishnan, R., \& Bhavani, R. R. (2018, July). Virtual reality learning environments for vocational education: A comparison study with conventional instructional media on knowledge retention. In 2018 IEEE 18th International Conference on Advanced Learning Technologies (ICALT) (pp. 385-389). IEEE.

Chang, H. Y. (2019). The Influence of Interactive Art of Visual Music on the Creativity of Science and Engineering Students. 2019 IEEE Global Engineering Education Conference (EDUCON), 1087-1092.

Chen, Y., Liou, S., \& Chen, L. (2018). The Relationships among Gender, Cognitive Styles, Learning Strategies, and Learning Performance in the Flipped Classroom. International Journal of Human-Computer Interaction, 00(00), 1-9.

Cheng, G. (2014). Exploring students' learning styles in relation to their acceptance and attitudes towards using Second Life in education: A case study in Hong Kong. Computers \& Education, 70, 105-115. https://doi.org/10.1016/j.compedu.2013.08.011

Dahlke, S. (2018). Connecting the dots: Backward course design, arts education, and teaching the holocaust. In Humanistic Pedagogy Across the Disciplines: Approaches to Mass Atrocity Education in the Community College Context (pp. 195-208).

de Bono, E. (1990). Lateral Thinking: A Textbook of Creativity. Penguin Books.

Dent, K. A. (1983). Cognitive Styles: Essence and Origins, by Herman A. Witkin and Donald R. Goodenough (Book Review). Journal of the American Academy of Psychoanalysis, 11(4), 635.

Dillon, P. C., Graham, W. K., \& Aidells, A. L. (1972). Brainstorming on a "hot" problem: Effects of training and practice on individual and group performance. Journal of Applied Psychology, 56(6), 487-490.

Doppelt, Y. (2009). Assessing creative thinking in design-based learning. International Journal of Technology and Design Education, 19(1), 55-65. 
Ehrman, M., \& Leaver, B. Lou. (2003). Cognitive styles in the service of language learning. System.

Fasko, D. (2001). Education and Creativity. Creativity Research Journal, 13(3-4), 317327.

Fried, J., \& Harper, R. (2018). Learning Everywhere on Campus: Teaching Strategies for Student Affairs Professionals. Retrieved from https://books.google.co.th/books?hl=th\&lr=\&id=mhQwDwAAQBAJ\&oi=fnd\&pg=PT1 $35 \& \mathrm{dq}=$ backward+design\&ots=PQ5RgBHH5c\&sig=GG9TxpvhDnyYPF5xQr5R1PNQ -ZM\&redir_esc $=\mathrm{y} \# \mathrm{v}=$ onepage $\& \mathrm{q}=$ backward design $\& \mathrm{f}=$ false

Gillan, C. M., \& Robbins, T. W. (2014). Goal-directed learning and obsessivecompulsive disorder. Philosophical Transactions of the Royal Society B: Biological Sciences.

Grootendorst, D. C., Gauw, S. A., Baan, R., Kelly, J., Murdoch, R. D., Sterk, P. J., \& Rabe, K. F. (2003). Does a single dose of the phosphodiesterase 4 inhibitor, cilomilast $(15 \mathrm{mg})$, induce bronchodilation in patients with chronic obstructive pulmonary disease? Pulmonary Pharmacology and Therapeutics, 16(2), 115-120.

Hahm, J., Kim, K. K., \& Park, S.-H. (2019). Cortical correlates of creative thinking assessed by the figural Torrance Test of Creative Thinking. NeuroReport, 30(18), 12891293.

Jelatu, S., Kurniawan, Y., Kurnila, V. S., Mandur, K., \& Jundu, R. (2019). Collaboration TPS learning model and m-Learning based on android for understanding of trigonometry concepts with different cognitive style. International Journal of Instruction, 12(4), 545-560.

Joyce, B. L., \& Swanberg, S. M. (2017). Using backward design for competency-based undergraduate medical education. Advancing Medical Education Through Strategic Instructional Design, 53-76.

Kangas, M. (2010). Creative and playful learning: Learning through game co-creation and games in a playful learning environment. Thinking Skills and Creativity, 5(1), 1-15.

Kelting-Gibson, L. (2003). Preservice teachers' planning and preparation practices: a comparison of lesson and unit plans developed using the backward design model and a traditional. Montana State University-Bozeman.

Krumm, G., Arán Filipppetti, V., Lemos, V., Koval, J., \& Balabanian, C. (2016). Construct validity and factorial invariance across sex of the Torrance Test of Creative Thinking - Figural Form A in Spanish-speaking children. Thinking Skills and Creativity, 22, 180-189.

Kuswanto, H. (2018). Android-Assisted Mobile Physics Learning Through Indonesian Batik Culture: Improving Students' Creative Thinking and Problem Solving. International Journal of Instruction, 11(4), 287-302. 
Lamb, R., Annetta, L., \& Vallett, D. (2015). The interface of creativity, fluency, lateral thinking, and technology while designing Serious Educational Games in a science classroom. Electronic Journal of Research in Educational Psychology, 13(2), 219-242.

Lo, J.-J., Chan, Y.-C., \& Yeh, S.-W. (2012). Designing an adaptive web-based learning system based on students' cognitive styles identified online. Computers \& Education, 58(1), 209-222.

Malang, U. N., Malang, U. N., \& Malang, U. N. (2017). Improving Creative Thinking Skills of Students through Differentiated Science Inquiry Integrated with Mind Map. 14(4), 77-91. https://doi.org/10.12973/tused.10214a

McAuliffe, M. (2016). The potential benefits of divergent thinking and metacognitive skills in STEAM learning: A discussion paper. International Journal of Innovation, Creativity and Change, 2(3), 71-82.

Moynihan, D. P. (2005). Goal-based learning and the future of performance management. Public Administration Review.

Mugisha, S. (2009). Managing water supply systems using lateral thinking techniques: Practical applications in East Africa. Leadership and Management in Engineering, 9(2), 83-89.

Noh, Y., Kang, J. A., \& Jung, E. J. (2015). A qualitative evaluation research on the relationship between creative thinking and an infinite creative space program. Journal of Korean Library and Information Science Society, 46(2), 71-111.

Noppe, L. D., \& Gallagher, J. M. (2010). A Cognitive Style Approach to Creative Thought. (May 2015), 37-41.

Nuha, A., Waluya, S. B., \& Junaedi, I. (2018). Mathematical Creative Process Wallas Model in Students Problem Posing with Lesson Study Approach. International Journal of Instruction, 11(2), 527.

Oltman, P. K., Raskin, E., \& Witkin, H. A. (1971). The group embedded figures test. Palo Alto Calif.: Consulting Psychologists Press.

Ontaneda Rea, M., \& Sánchez Román, J. L. (2019). Implementing backward design to improve students' academic performance in EFL classes. Espirales Revista Multidisciplinaria de Investigación, 3(24), 37-49.

Onyekuru, B. U. (2015). Field Dependence-Field Independence Cognitive Style, Gender, Career Choice and Academic Achievement of Secondary School Students in Emohua Local Government Area of Rivers State. Journal of Education and Practice, 6(10), 76-85.

Perry, A., \& Karpova, E. (2017). Efficacy of teaching creative thinking skills: A comparison of multiple creativity assessments. Thinking Skills and Creativity, 24, 118126. 
Rahardjanto, A., Husamah, \& Fauzi, A. (2019). Hybrid-PjBL: Learning outcomes, creative thinking skills, and learning motivation of preservice teacher. International Journal of Instruction, 12(2), 179-192.

Raptis, G. E., Fidas, C. A., \& Avouris, N. M. (2016). Differences of field dependent/independent gamers on cultural heritage playing: Preliminary findings of an eye-tracking study. Lecture Notes in Computer Science (Including Subseries Lecture Notes in Artificial Intelligence and Lecture Notes in Bioinformatics), 10059 LNCS, 199-206.

Rawlinson, J. G. (2017). Creative Thinking and Brainstorming. Taylor \& Francis.

SEMERCI, N. (2017). Pedagogical Formation Students' Dispositions toward Lateral Thinkin. Bartın Üniversitesi Eğitim Fakültesi Dergisi, 6(1), 336-336.

Setiawan, Y. E., Purwanto, Parta, I. N., \& Sisworo. (2020). Generalization strategy of linear patterns from field-dependent cognitive style. Journal on Mathematics Education, 11(1), 77-94.

Sujito, \& Muttaqin, W. M. (2020). Integrating instruction approach with learners' cognitive style to enhance EFL indonesian students' writing achievement. International Journal of Instruction, 13(1), 623-636.

Tan, A.-G. (2007). Creativity - A Handbook for Teachers. Citeseer.

Thornton, A., \& Lukas, D. (2012). Individual variation in cognitive performance: developmental and evolutionary perspectives. Philosophical Transactions of the Royal Society of London B: Biological Sciences, 367(1603), 2773-2783.

Thousand, J. S., Villa, R. A., \& Nevin, A. (1994). Creativity and Collaborative Learning: A practical guide to empowering students and teachers. Paul H. Brookes Pub.

Torrance, E. P. (1962). Guiding creative talent. American Psychological Association, xi 278 pp.

Torrance, E. P. (1967). Torrance Tests of Creative Thinking. Journal of Educational Measurement.

Torrance, E. P. (1972). Predictive Validity of the Torrance Tests of Creative Thinking. The Journal of Creative Behavior, 6(4), 236-262.

Tsai, M.-C., \& Lin, H.-C.-K. (2017). A Study on the Behavioral Patterns Formed by Subjects with Different Cognitive Styles in Playing Augmented Reality Interaction Games. In SETE 2017 (Vol. 10676, pp. 372-381). Cape Town, South Africa: Springer, Cham.

White, G. E. (1972). Creativity: The $\mathrm{x}$ factor in advertising theory. Journal of Advertising, 1(1), 28-32. Wiggins, G \& McTighe, J. (2005). Understanding by Design, Expanded Second Edition. 2005.

Wiggins, G. P., \& McTighe, J. (2007). Understanding Design. Design Expertise. 
Wiggins, G., \& McTighe, J. (1998). Chapter 1 . What Is Backward Design? In Understanding by Design.

Witkin, H. A., Moore, C. A., Goodenough, D., \& Cox, P. W. (1977). Field-Dependent and Field-Independent Cognitive Styles and Their Educational Implications. Review of Educational Research, 47(1), 1-64.

Wojciehowski, M., \& Ernst, J. (2018). Creative by Nature: Investigating the Impact of Nature Preschools on Young Children's Creative Thinking. International Journal of Early Childhood Environmental Education, 6(1), 3-20. Retrieved from https://eric.ed.gov/?id=EJ1193490

Yang, T., Hwang, G., \& Yang, S. J. (2013). Development of an Adaptive Learning System with Multiple Perspectives based on Students' Learning Styles and Cognitive Styles. Educational Technology \& Society, 16, 185-200.

Yusnaeni, Y., Corebima, A. D., Susilo, H., \& Zubaidah, S. (2017). Creative thinking of low academic student undergoing search solve create and share learning integrated with metacognitive strategy. International Journal of Instruction, 10(2), 245-262.

Zhang, X., Kwan, H. K., \& Kwan, H. K. (2018). Empowering Leadership and Team Creativity: The Roles of Team Learning Behavior, Team Creative Efficacy, and Team Task Complexity. Routledge. 